Check for updates

Montreal

Cite this as: BMJ2020;370:m3512 http://dx.doi.org/10.1136/bmj.m3512 Published: 09 September 2020

\section{Covid-19: Pharma companies promise not to bow to political pressure to rush vaccine production}

\author{
Owen Dyer
}

The chief executive officers (CEOs) of nine drug companies working towards a covid-19 vaccine have issued a joint statement promising to "only submit [a vaccine] for approval or emergency use authorisation after demonstrating safety and efficacy through a Phase 3 clinical study."

"We pledge to always make the safety and well-being of vaccinated individuals our top priority," wrote the CEOs of AstraZeneca, BioNTech, GlaxoSmithKline, Johnson \& Johnson, Merck, Moderna, Novavax, Pfizer, and Sanofi on 8 September in a statement entitled Biopharma Leaders Stand With Science. ${ }^{1}$

The statement follows an open letter by seven drug industry CEOs last week urging that "political considerations should be put aside" in covid-19 drug and vaccine development and that clinical data should be publicly disclosed. ${ }^{2}$

The US president, Donald Trump, who pledged a vaccine before the year's end at his party convention, has alleged that "deep state" actors at the Food and Drug Administration are slowing down the vaccine development process to hurt him politically. The FDA commissioner, Stephen Hahn, said on 30 August that his agency might not wait for full phase III trial results-the normal standard required in approving medicines-before granting emergency use authorisation to a covid-19 vaccine.

\section{Dubious claims}

The CEOs' promise came as Trump reiterated his frequent claim that a vaccine could be ready before the presidential election on 3 November, ${ }^{3}$ a claim refuted by his own government's health officials. "We'll have the vaccine soon, maybe before a special date," Trump said at a 7 September press conference. "You know what date I'm talking about."

The developers' public refusal to submit vaccines without phase III results is widely seen as an implicit rebuke of the administration, as well as an effort to shore up public confidence in vaccines at a time when suspicion and misinformation are rife in the United States.

Peter Hotez, dean of tropical medicine at Baylor College of Medicine in Houston, told CNN, "The fact that pharmaceutical companies are sort of protecting the US population from the government is certainly something I've never seen." In June the FDA withdrew its hasty emergency authorisation of hydroxychloroquine and chloroquine, drugs that Trump repeatedly promoted for treating covid-19, after they were shown to do more harm than good.

The agency was again accused of bowing to political pressure last month when its emergency use authorisation of convalescent plasma, critics alleged, was timed to coincide with the opening of the Republican Party conference, where Trump touted it as a breakthrough. Hahn falsely claimed a 35\% survival benefit in covid-19 patients treated with convalescent plasma, a claim that he later retracted.

The avalanche of dubious claims has bred mistrust. A STAT/Harris poll last week found that $78 \%$ of the public were worried that the vaccine approval process was driven primarily by politics, not science. ${ }^{4}$ Public health experts fear that the anti-vaccine movement, which has strengthened during the pandemic, will pounce on any misstep to discredit vaccines in general.

The CEOs' statement did not commit to making trial data transparent, a demand of the Democratic candidate, Joe Biden. It also disappointed some public health advocates by not ruling out an emergency use authorisation, leaving open the possibility of an application before the scheduled end of phase III trials if safety and efficacy are demonstrated early.

\footnotetext{
Soriot P, Sahin U, Walmsley E, et al. Biopharma leaders unite to stand with science. 8 Sep 2020. https://www.astrazeneca.com/media-centre/press-releases/2020/biopharma-leaders-unite-to-stand-with-science.html.

Levin JM, Hastings PJ, Love TW, et al. An open letter to the biopharmaceutical industry. 3 Sep 2020. https://www.bio.org/sites/default/files/202009/An_Open_Letter_to_the_Biopharmaceutical_Industry.pdf.

3 Tanne JH. Covid-19: CDC says vaccine is coming before November US election. BMJ2020;370:m3478. doi: 10.1136/bmj.m3478 pmid: 32887676

4 Silverman E. Poll: Most Americans believe the Covid-19 vaccine approval process is driven by politics, not science. 31 Aug 2020. https://www.statnews.com/pharmalot/2020/08/31/most-americans-believe-the-covid-19-vaccine-approval-process-is-driven-by-politics-not-science/.
}

This article is made freely available for use in accordance with BMJ's website terms and conditions for the duration of the covid-19 pandemic or until otherwise determined by BMJ. You may use, download and print the article for any lawful, non-commercial purpose (including text and data mining) provided that all copyright notices and trade marks are retained. 